\title{
Yeni Planlı Alanlar İmar Yönetmeliğinin İnşaat Sektöründeki Yansımaları Üzerine Bir Çalışma
}

\author{
Savaş Bayram ${ }^{1 *}$ \\ ${ }^{1}$ Erciyes Üniversitesi, Mühendislik Fakültesi, İnşaat Mühendisliği Bölümü, Kayseri, Türkiye (ORCID: 0000-0002-0153-6750)
}

(İlk Geliş Tarihi 18 Temmuz 2019 ve Kabul Tarihi 21 Ekim 2019)

(DOI: $10.31590 /$ ejosat.593868)

ATIF/REFERENCE: Bayram, S. (2019). Yeni Planlı Alanlar İmar Yönetmeliğinin İnşaat Sektöründeki Yansımaları Üzerine Bir Çalı̧ma. Avrupa Bilim ve Teknoloji Dergisi, (17), 96-102.

$\ddot{O} \mathbf{z}$

Türkiye'de modern imar planlamasının ilk adımları 1928 yılında atılmış olup, güncel imar uygulamalarına uyum sağlanabilmesi amacıyla imar mevzuatında yapılan güncellemeler yaklaşık yüz yıldır devam etmektedir. Son olarak 2017 yılında Planlı Alanlar İmar Yönetmeliği yürürlüğe girmiş ve imar uygulamalarında önemli değişiklikler getirmiş̧tir. Ancak mevzuatta yapılan bu tür değişiklikler akademik çalışmalarda kısıtlı olarak incelenmektedir. Kısıtlı sayıda yapılan bu araştırmalar da Türkiye'de uygulamadan sorumlu idarelerin imar planı uygulamalarında çeşitli sorunlarla karşılaştıklarını göstermektedir. Hâlbuki imar kapsamındaki mevzuat değişikliklerinin inşaat sektörü çalışanları tarafından doğru olarak anlaşılabilmesi, uygulamada yaşanan problemlerin minimize edilmesi açısından son derece önemlidir. Bu çalışmada, Planlı Alanlar İmar Yönetmeliği kapsamında değiştirilen ve yeni eklenen düzenlemelere inşaat sektöründe çalışmakta olan inşaat mühendisleri ve mimarların bakış açılarının ve güncel mevzuat farkındalık düzeylerinin belirlenebilmesi amacıyla toplam 20 sorudan oluşan bir anket çalışması uygulanmış ve katılımcıların yeni imar yönetmeliğinde yapılan düzenlemeler ile ilgili düşünceleri değerlendirilerek elde edilen sonuçlar tartışılmıştır. Bu kapsamda katılımcıların demografik özelliklerinin belirlenmesinin yanında beşli likert ölçeği de kullanılmıştır. Özellikle tartışmalı konulardan olan; konutlarda minimum 1+1 tasarımın zorunlu hale gelmesinin ‘önem derecesi düşük' gösterge olarak değerlendirildiği, taban alanı katsayısının (TAKS) \%60’ı geçmemesi şartıyla uygulama yapılabilmesi hususunun 'ortalama' gösterge olarak değerlendirildiği, bodrum kat dairelere gün ışığı alma koşulu getirilmesi hususunun 'yüksek' gösterge olarak değerlendirildiği sonuçlarına ulaşılmıştır.

Anahtar Kelimeler: İnşaat sektörü, İmar uygulamaları, Planlı Alanlar İmar Yönetmeliği, İnşaat mühendisi, Mimar.

\section{A Study on the Reflections of the New Planned Areas Zoning Regulation in the Construction Sector}

\begin{abstract}
In Turkey, the first steps of the modern urban planning were taken in 1928. The zoning legislation updates have been proceeding for nearly a hundred years in order to adapt to the modern zoning practices. Finally, in 2017, the Planned Areas Zoning Regulation entered into force and introduced significant changes in the zoning practices. However, such changes in the legislation are limited in academic studies. The limited number of these studies also indicate that the governmental administrations, responsible for implementation, encounter various problems in terms of zoning plan applications. The reality on the other hand is that it is very significant for the construction sector's employees to perceive the legislative changes correctly in order to minimize the problems in practice. In this study, a survey consisting of 20 questions was applied to determine the perspectives of civil engineers and architects, actively working in the Turkish construction sector. The purpose of the study was to determine the awareness level of the respondents
\end{abstract}

\footnotetext{
* Sorumlu Yazar: Erciyes Üniversitesi, Mühendislik Fakültesi, İnşaat Mühendisliği Bölümü, Kayseri, Türkiye, ORCID: 0000-0002-0153-6750, sbayram@erciyes.edu.tr
} 
related to new Planned Areas Zoning Regulation. The findings were evaluated, and the results were discussed. In this context, a fivepoint Likert scale was used besides the demographic characteristics of the participants. Particularly the controversial issues as; the necessity of minimum $1+1$ design in the residences is considered as a 'low level' indicator, where the application of the building coverage ratio should not exceed $60 \%$ is considered as an 'average' indicator, and the requirement to bring daylight into the basement flats is considered as a 'high level' indicator.

Keywords: Construction sector, Zoning practices, Planned Areas Zoning Regulation, Civil Engineer, Architect.

\section{Giriş}

Türkiye'de yapılaşma ve şehirleşme, temel olarak 1985 yılından bu yana yürürlükte olan 3194 sayılı İmar Kanunu ve bu kanunun genel hükümlerine açıklık getirmek üzere yayımlanan İmar Yönetmelikleri hükümlerine göre yürütülmektedir. Daha eskiye dönüldüğünde, modern anlamda ilk imar planlaması, 1928 yılında yayımlanan 1351 sayılı Ankara İmar Müdürlüğü Kuruluş ve Görevini Tayin Eden Kanun ile hayata geçirilmiştir. 1930 tarih ve 1580 sayılı Belediye Kanunu ile bütün belediyelerin imar planı yapmaları zorunluluğu getirilmiş olup, 1933 yılında da her kentte planlama çalışmalarını düzenlemek amacıyla 2290 sayılı Belediye ve Yollar Kanunu yürürlük kazanmıştır (Özkaya, 2000). Türkiye Cumhuriyeti tarihinde imara ilişkin çalışmalar yaklaşık yüz yıldır devam etmekte olup, özellikle ikinci dünya savaşı sonrasında başlayan köyden kente göç nedeniyle ivme kazanmış ve 1950 yılından sonra çok sayıda kanun, tüzük, yönetmelik ve genelge yürürlüğe konulmuştur. İmar Hukukunda İmar Kanunundan sonra en fazla kullanılan kaynaklar; Mekânsal Planlar Yapım Yönetmeliği, Planlı Alanlar İmar Yönetmeliği ve Plansız Alanlar İmar Yönetmeliği olarak sıralanmıştır (Öngören, 2017).

Türkiye'nin gelişmekte olan ülkeler sınıfında bulunması ve modern imar uygulamalarına uyum sağlayabilmesi amacıyla imar mevzuatında yapılan güncellemeler kaçınılmazdır. Türkiye'nin çeşitli yerleşim birimlerinde global ölçekte yaşanan kentsel dönüşüm süreci de kentleşmeye yönelik yaklaşımların, mevcut imar planlarının ve bunların uygulamasının yeniden gözden geçirileceği bir dönem olarak algılanmalıdır (İnam vd., 2015). Ancak imar mevzuatından beklenilenin gerçekleşmesi; belediyelerin parasal imkânlarla birlikte yeter sayıda ve tecrübeli teknik eleman çalıştırabilme imkân ve ortamına kavuşturulmalarına, planların gecikmesiz ve yansız uygulamasını sağlayıcı önlemlerin alınmasına ve özellikle konu hakkında belde halkının aydınlatılmasına bağlıdır. Bu kapsamda 1985 yılında yürürlüğe giren, yaklaşık 32 yıl yürürlükte kalan ve bu süreçte on beşin üzerinde değişikliğe uğrayan Planlı Alanlar Tip İmar Yönetmeliği, yerini 03/07/2017 tarihinde yayımlanan ve kısa sürede dört revizyona uğrayan Planlı Alanlar İmar Yönetmeliği'ne bırakmıştır. Dünya genelinde, örneğin Tayvan'da deprem riski altındaki bölgelerdeki imar düzenlemelerinin 2002 yılından bu yana arazi kullanımı ve mülk işlemlerine nasıl yansıdığı dahi incelenmişken (Chen ve Chang, 2018), yeni imar yönetmeliğinin Türk inşaat sektörüne yansımaları kapsamında yeterli düzeyde akademik çalışma yapılmamıştır. Kısıtlı sayıda yapılan araştırmalar da Türkiye'de uygulamadan sorumlu idarelerin imar planı uygulamalarında çeşitli sorunlarla karşılaştıklarını göstermektedir. Bu sorunlar, genel olarak; uygulama sorunları, kurumsal sorunlar ve sosyal sorunlar olarak sınıflandırılmaktadır (Yıldı, 1992; Çay ve Özen, 1998; Sağlam, 2003). Örneğin Yıldız (1992); kamulaştırma, ifraz, arazi ve arsa düzenlemeleri gibi uygulamalarda karşılaşılan sorunları teknik, ekonomik ve hukuki sorun1ar altında incelemiş olup, planın uygulanmasını engelleyen hukuki mevzuata ilişkin bazı hükümlerin tekrar gözden geçirilmesi gerektiğini ifade etmiştir. Çay ve Özen (1998), 18 uygulaması ile düzenlemeye alınan ve yapılaşmaya uygun olmayan kadastro parsellerinin imar parseline dönüştürülebildiğini, hâlbuki topografik yapı bozuk olduğu için plancının bu gibi yerleri genellikle yeşil alan olarak ayırdığını, bu nedenle bu gibi alanların düzenleme dışı bırakılması gerektiğini ifade etmişlerdir. Literatürde yer bulan diğer bir sorun da imar mevzuatının mimari tasarıma getirdiği sınırlamalardır. Sonkaya (2017); Büyükşehir Belediyesi İmar Yönetmeliklerinde, Planlı Alanlar Tip İmar Yönetmeliğine aykırı hükümlerin yer almakta olduğunu ve bu nedenle mevzuatta çelişkiler ortaya çıktığını, merkez ve ilçe Belediyelerinde imar mevzuatının farklı algılandığını ve farklı uygulandığını, bu durumun doğrudan kentleşmeye yansıdığını ve kamu yararı hiçe sayılarak kamu düzeninin korunamadığını vurgulamıştır. Hatta yapısal tasarım sürecinde karşılaşılan mühendislik sorunları mimarlık açısından inceleme alanı da bulmuştur. Çambel ve Özgan (2018), Bolu ve Düzce'de görev yapan 73 mimara uyguladıkları anket çalışması kapsamında; döşeme kalınlığında müdahale olduğu, çatı detayına müdahalenin en çok saçak detayında ortaya çıktığı vb. sonuçlara ulaşmışlardır. Literatürde yer alan çalışmalardan da anlaşıldığı üzere, imar kapsamındaki mevzuat değişikliklerinin inşaat sektörü çalışanları tarafından doğru olarak anlaşılabilmesi son derece önemlidir. Bu çalışmada, Planlı Alanlar İmar Yönetmeliği kapsamında değiştirilen ve yeni eklenen düzenlemelere inşaat sektöründe çalışmakta olan inşaat mühendisleri ve mimarların bakış açılarının ve mevzuata hâkimiyet düzeylerinin belirlenebilmesi amacıyla toplam 20 sorudan oluşan bir anket çalışması uygulanmış ve katılımcıların bahsi geçen değişiklikler hakkındaki düşünceleri değerlendirilerek elde edilen sonuçlar tartışılmıştır.

\section{Materyal ve Metot}

Planlı Alanlar İmar Yönetmeliğinin 03/07/2017 tarihinde yayımlanması ile imar uygulamalarında birçok önemli düzenleme ve değişiklik getirilmiştir. Örneğin, 02/11/1985 tarihli Planlı Alanlar Tip İmar Yönetmeliğinde yer alan ve mülga (kaldırılan) yönetmeliklere uyma imkânı tanıyan geçici maddelerin 01/10/2017 tarihi itibariyle yürürlükten kaldırılarak, imar disiplinini bozan birden fazla yönetmeliğin tercih edilebilmesi uygulamasına son verilmesi amaçlanmıştır. Bunun yanısıra her bölgenin coğrafi, tarihi, kültürel ve yöresel özelliklerine göre ayrı ayrı imar düzenlemeleri yapılabilmesi ve imar düzenlemelerinin yerelde hazırlanarak denetim yetkisine sahip Çevre ve Şehircilik Bakanlığına gönderilmesi gibi önemli düzenlemeler getirilmiştir.

Özet olarak, 2017 yılı sonlarından bu yana geçen yaklaşık bir yılda dört değişiklik yapılan Planlı Alanlar İmar Yönetmeliği göz önüne alındığında; 
- 30/09/2017 tarihli ve toplam 16 maddeden oluşan birinci değişiklik kapsamında; 'atrium' tanımı değiştirilmiş, emsal harici alanlar ile parselin toplam emsale esas alanı arasındaki ilişki düzenlenerek emsal haricinde kalan kısımlar tanımlanmış, riskli alan kapsamına alınmış yapıların ruhsat işlemleri ile tadilat ruhsatı başvuru şekilleri düzenlenmiştir.

- 06/02/2018 tarihli ve toplam üç maddeden oluşan ikinci değişiklik kapsamında; projelerin incelenmesi yetkisinin 'idare' yerine 'idarelerin en az 1 yıl deneyimi haiz teknik personeli’ tarafından yapılması değişikliği getirilmiştir.

- 28/07/2018 tarihli ve toplam altı maddeden oluşan üçüncü değişiklik kapsamında; asansör yeri ve asansör tesisi için kat sınırları düzenlenmiş olup, ifraz, tevhit ve parsel sınırı düzeltme işlemleri netleştirilmiş, kademe uygulaması detaylandırılmış, tadilat ruhsatı başvuru şekli yeniden düzenlenmiştir.

- 27/10/2018 tarihli ve toplam beş maddeden oluşan dördüncü değiş̧iklik kapsamında; yapı kullanma izin belgesi ve yapı ruhsatı yeniden tanımlanarak örnek formlara yer verilmiş olup, kot farkı 3,50 metreden fazla olan binaların kotunun nasıl belirleneceği netleştirilmiştir.

Planlı Alanlar İmar Yönetmeliği kapsamında yapılan önemli düzenlemelerin bir kısmı, aşağıda sıralanmıştır (Çevre ve Şehircilik Bakanlı̆̆ 1 2017):

- 5. maddenin 6. fikrası (TAKS sinıri),

- 5. maddenin 25. fikrası (konut için bağımsız bölümler),

- 28. maddenin 7. fikrası (mimari estetik komisyon kararı),

- 40. maddenin 11. fikrası (dış cephe boya ve kaplamaları ile çatı malzemesi ve rengi),

- 44. maddenin 2. fikrası (kapıcı daireleri ve bekçi odaları),

- 62. maddenin 1. fikrası (Bilgi Teknolojileri ve İletişim Kurumunun uygun görüşü).

Uygulamanın odak noktasını, yukarıda bir kısmı verilen ihtilaflı maddeler oluşturmaktadır.

\section{Araştırma Sonuçları ve Tartışma}

Çalışmada veri toplama aracı olarak anket yöntemi kullanılmıştır. Anket, gözlemleri standartlaştırmak üzere başvurulan araçlardan birisidir. Anket, belli bir konuda saptanmış hipotezlere ya da sorulara bağlı olarak bir evren ya da örneklemi oluşturan kaynak kişilere sorular yöneltmek suretiyle sistemli veri toplama tekniği olarak tanımlanabilir (Balcı, 2005). Anket, kaynak kişilerin okur-yazar olmalarını gerektirir. Bu nedenle yazılı veri toplama aracı olarak da tanımlanabilmektedir. Bu çalışmada, inşaat sektöründe çalışmakta olan toplam 69 inşaat mühendisi ve mimara 20 sorudan oluşan bir anket çalışması uygulanmıştır. Bu kapsamda ilk dört soru demografik özelliklere, geriye kalan 16 soru da beşli likert ölçeği $(1=$ kesinlikle katılmıyorum, $5=$ kesinlikle katıllyorum) kullanılarak Planlı Alanlar İmar Yönetmeliğinin inşaat sektöründeki yansımalarına ayrılmıştır. Detaylar Tablo 1'de verilmiştir.

Tablo 1. Ölçekler ve Sinır Değerler (Memnun vd., 2012)

\begin{tabular}{c|c|c|c|c|c}
\hline Ölçek & $\mathbf{1}$ & $\mathbf{2}$ & $\mathbf{3}$ & $\mathbf{4}$ & $\mathbf{5}$ \\
\hline Sinır değer & $\mathbf{1 , 0 0 - 1 , 8 0}$ & $\mathbf{1 , 8 1 - 2 , 6 0}$ & $\mathbf{2 , 6 1 - 3 , 4 0}$ & $\mathbf{3 , 4 1 - 4 , 2 0}$ & $\mathbf{4 , 2 1 - 5 , 0 0}$ \\
\hline Sonuç & $\begin{array}{c}\text { Kesinlikle } \\
\text { Katılmiyorum }\end{array}$ & Katılmıyorum & Fikrim Yok & Katıliyorum & $\begin{array}{c}\text { Kesinlikle } \\
\text { Katıllyorum }\end{array}$ \\
\hline
\end{tabular}

Katılımcıların 50'si (\%72) inşaat mühendisi ve 19’u (\%28) mimar olup, katılımcı profili ağırlıklı olarak özel sektör çalışanlarından (\%78) oluşmaktadır. Ayrıca katılımcıların \%14'ünü akademik personel, \%8'ini de kamu çalışanları oluşturmaktadır. Katılımcıların mesleki deneyimleri Şekil 1'de sunulmuştur.

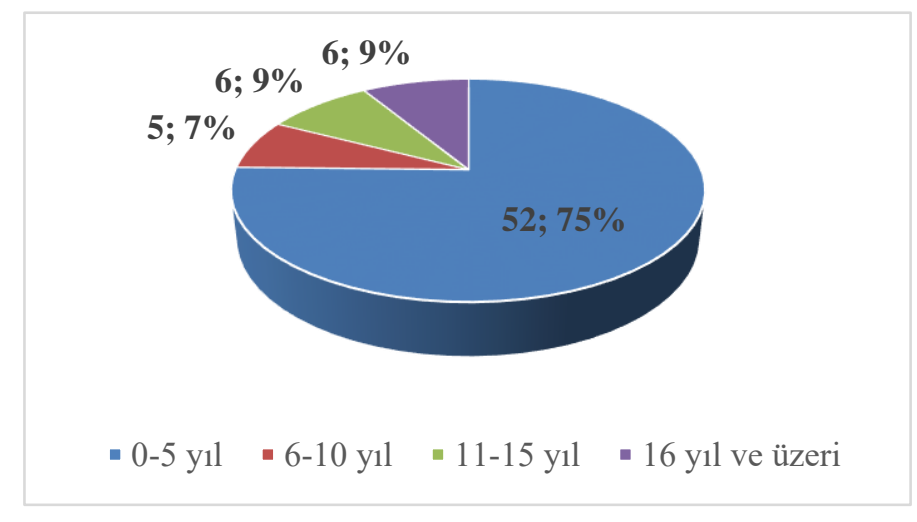

Şekil 1. Mesleki Deneyim 

sahiptir.

Katılımcılar, ağırlıklı olarak yeni mezun profiline sahiptir. Katılımcıların yaklaşık beşte biri ise sektörde 10 yıl üzeri deneyime

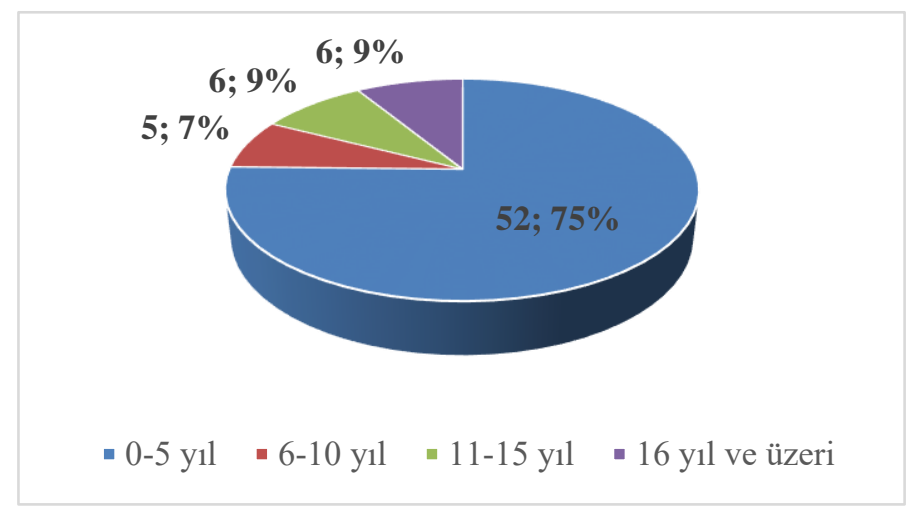

Şekil 2. Yeni Yönetmeliğe Hâkimiyet Düzeyi

Katılımcıların yarısından fazlası (\%52), Planlı Alanlar İmar Yönetmeliğine genel anlamda yeterince hâkim olmadıklarını beyan ederken, üst düzeyde hâkim olduklarını beyan edenlerin oranı \%7'yi geçmemektedir.

Beşli likert ölçeğinde tanımlanan 16 soru için ölçek güvenirliği değerlendirilmiştir. Bu kapsamda, iç tutarlılık adına sıklıkla kullanılan bir ölçüm olan Cronbach's Alpha katsayısı $(\alpha)$ hesaplanmışıtı. ( $\alpha$ ), ölçekte bulunan maddelerin homojen yapısını açıklamak veya sorgulamak üzere kullanılmaktadır. $(\alpha)$ değeri yüksek olan ölçek, maddelerinin birbirleriyle tutarlı olduğu şeklinde yorumlanır (Yıldız ve Uzunsakal, 2018). ( $\alpha$ ) değeri aşă̆ıdaki formülle hesaplanır (Alpar, 2013);

$$
\alpha=\left(\frac{k}{k-1}\right) x\left(1-\frac{\sum_{i=1}^{k} \sigma^{2} y i}{\sigma^{2} x}\right)
$$

Burada; K: Madde sayısı (likert ölçeği ile hazırlanan soru sayısı), $\sigma_{y y}^{2}$ : i. maddenin toplam örneklemdeki varyansl, $\sigma_{x}^{2}$ : Toplam test skorunun varyansı olarak ifade edilir. Bu çalışma kapsamında beşli likert ölçeğinde sunulan toplam 16 soru için $\alpha=0,78$ olarak hesaplanmıştır. Literatürde, $\alpha$ değeri 0,70 ve üzerinde olan ölçümlerin güvenilir olduğu kabul edilmektedir (Bernardi, 1994). Sınır değer olarak 0,70 değeri göz önünde bulundurulduğunda, ölçeğin güvenilir olduğu söylenebilir. Katılımcılara yöneltilen sorulardan elde edilen ortalama ve standart sapma değerleri Tablo 2'de sunulmuştur. Buna göre 1, 5 ve 13 no'lu sorular genel nitelikte olup, diğer sorular 2. bölümün sonunda bahsi geçen madde hükümlerine dayanılarak hazırlanmıştır.

Tablo 2. Anket Çalışmasından Elde Edilen Sonuçlar

\begin{tabular}{|c|c|c|c|}
\hline No & Açıklama & $(\overline{\mathbf{x}})$ & $(\sigma)$ \\
\hline 1 & Yeni planlı alanlar imar yönetmeliği çarpık kentleşmeyi ortadan kaldıracaktır. & 2,81 & 1,075 \\
\hline 2 & $\begin{array}{l}\text { Yeni planlı alanlar imar yönetmeliğinin kentsel dönüşüme olumlu katkıs1 } \\
\text { olacaktır. (Madde 5/17) }\end{array}$ & 3,09 & 1,067 \\
\hline 3 & $\begin{array}{l}\text { Yeni planlı alanlar imar yönetmeliğinde taban alanı katsayısının (TAKS) \% } 40 \text { 'tan } \\
\% 60 \text { 'a çıkarılabilmesi yeşil alan sorunu oluşturacaktır. (Madde } 5 / 6 \text { ) }\end{array}$ & 3,72 & 1,403 \\
\hline 4 & $\begin{array}{l}\text { Yeni planlı alanlar imar yönetmeliğinde TAKS'ın \%40’tan \%60'a çıkarılabilmesi } \\
\text { yatay kentleşmeyi olumlu yönde etkileyecektir. (Madde 5/6) }\end{array}$ & 3,14 & 1,154 \\
\hline 5 & Yeni planlı alanlar imar yönetmeliği çarpık kentleşmeyi ortadan kaldıracaktır. & 2,75 & 1,143 \\
\hline 6 & $\begin{array}{l}\text { Yeni planlı alanlar imar yönetmeliği mimari estetiğe katkı sağlayacaktır. } \\
\text { (Madde 28/7) }\end{array}$ & 2,74 & 1,146 \\
\hline 7 & $\begin{array}{l}\text { Yeni planlı alanlar imar yönetmeliği kapsamında belediyelere dış cephe renkleri } \\
\text { ve çatı detayları gibi konularda düzenleme yetkisi verilmesi, yerel mimariyi } \\
\text { geliştirecektir. (Madde 40/11) }\end{array}$ & 2,99 & 1,299 \\
\hline 8 & $\begin{array}{l}\text { Yeni planlı alanlar imar yönetmeliğindeki; "Silueti olumsuz etkilememek } \\
\text { kaydıyla Bilgi Teknolojileri ve İletişim Kurumunun uygun görüşü alınarak; } \\
\text { ruhsat alınmadan elektronik haberleşme (baz) istasyonu kurulabilir" ifadesi } \\
\text { olumlu bir iyileştirmedir. (Madde 62/1) }\end{array}$ & 2,71 & 1,305 \\
\hline
\end{tabular}


Tablo 2. Anket Çalışmasından Elde Edilen Sonuçlar (Devamı)

\begin{tabular}{|c|c|c|c|}
\hline No & Açıklama & $(\overline{\mathbf{x}})$ & $(\sigma)$ \\
\hline 9 & $\begin{array}{l}\text { Yeni planlı alanlar imar yönetmeliğindeki; "Güneş kaynaklı yenilenebilir enerji } \\
\text { sistemleri ruhsata tabi değildir" ifadesi (güneş enerji santrallerinde ruhsat } \\
\text { aranmaması) olumlu bir iyileştirmedir. (Madde 59/2) }\end{array}$ & 3,74 & 1,241 \\
\hline 10 & $\begin{array}{l}\text { Yeni planlı alanlar imar yönetmeliğindeki; "giriş katların iş yeri olarak } \\
\text { kullanılacak olması" mevcut giriş katlardaki iş yerlerini mevzuata uygun hale } \\
\text { getirecektir. (Madde 46/1) }\end{array}$ & 3,54 & 0,969 \\
\hline 11 & $\begin{array}{l}\text { Yeni planlı alanlar imar yönetmeliğindeki; "Fenni mesullerden mimar veya inşaat } \\
\text { mühendisi; } 30.000 \mathrm{~m}^{2} \text { den fazla inşaatın fenni mesuliyetini aynı anda } \\
\text { üstlenemez" ibaresini destekliyorum. (Madde } 68 / 13 \text { ) }\end{array}$ & 3,90 & 1,108 \\
\hline 12 & $\begin{array}{l}\text { Yeni imar yönetmeliğinde "1+0 stüdyo dairelerin kaldırılması"nı destekliyorum. } \\
\text { (Madde 5/25) }\end{array}$ & 2,87 & 1,495 \\
\hline 13 & Yeni imar yönetmeliği maddeleri oldukça açıklayıcı ve anlaşılırdır. & 2,94 & 0,814 \\
\hline 14 & $\begin{array}{l}\text { Yeni imar yönetmeliğinde "gün 1şı̆̆ almayan bodrum kat dairelerinin } \\
\text { yasaklanması"nı destekliyorum. (Madde 44/2) }\end{array}$ & 4,04 & 1,309 \\
\hline 15 & $\begin{array}{l}\text { Yeni imar yönetmeliğinde "otoparkın emsalden sayılmaması" otopark } \\
\text { sorununun çözülmesine katkı sağlayacaktır. (Madde 22/1) }\end{array}$ & 3,57 & 1,213 \\
\hline 16 & $\begin{array}{l}\text { Yeni imar yönetmeliğinde; inşaat ruhsatı beklenmeden mimari proje onayına } \\
\text { müteakip kazı izni verilmesi imkânının getirilmesi, projelerin hazırlanması ve } \\
\text { ruhsatın düzenlenmesi için geçen 3-4 aylık sürede kazı imalatlarının } \\
\text { yapılabilmesine olanak sağlayacak ve yatırımcı zaman kazanacaktır. (Madde } \\
\text { 59/3) }\end{array}$ & 3,60 & 1,199 \\
\hline \multicolumn{2}{|c|}{ ORTALAMA } & 3,26 & 1,184 \\
\hline
\end{tabular}

Tablo 2, toplam 16 sorudan elde edilen aritmetik ortalama sonuçlarından dokuzunun ' 3 ' aralığında $(2,61-3,40)$ ve yedisinin ' 4 ' aralığında $(3,41-4,20)$ olduğunu göstermektedir. Buna göre genel değerlendirme, verilen hükümlere nötr yaklaşım ve katılma eğilimini işaret etmektedir. En fazla desteklenen husus; yeni yönetmelikte bodrum kat dairelerinin yasaklanması olurken (soru 14), en az desteklenen husus; ruhsat alınmadan sadece BTK'nın uygun görüşü alınarak baz istasyonu kurulabilmesi (soru 8) olarak görülmektedir. Bunu yanısıra, 13. soru dışındaki bütün soruların standart sapması 1,000 değerinden büyük olarak elde edilmiştir. Böylece, verilen cevapların değişken oldukları ve genel olarak katılımcılar arasında fikir birliğinin bulunmadığı ifade edilebilir.

Çalışma kapsamında, inşaat mühendisi ve mimar çalışanların ayrı ayrı göreceli öneme sahip algılarını belirlemek için her bir soruya verdikleri cevapların rölatif önem endeksi (RÖE) değerleri (relative importance index, RII) de hesaplanmıştır. RÖE değerleri aşağıdaki formüle göre hesaplanmıştır (Gündüz vd., 2013):

$$
R \ddot{O} E=\frac{\sum W}{A x N}=\frac{5 n_{5}+4 n_{4}+3 n_{3}+2 n_{2}+1 n_{1}}{5 x N}
$$

Burada; W: Her soruya verilen cevapların ă̆ırlık değgerini (bu çalışmada 1'den 5'e kadar), A: En yüksek ă̆ırlık katsayısını (bu çalışmada 5), N: toplam katılımcı sayısını ifade etmektedir.

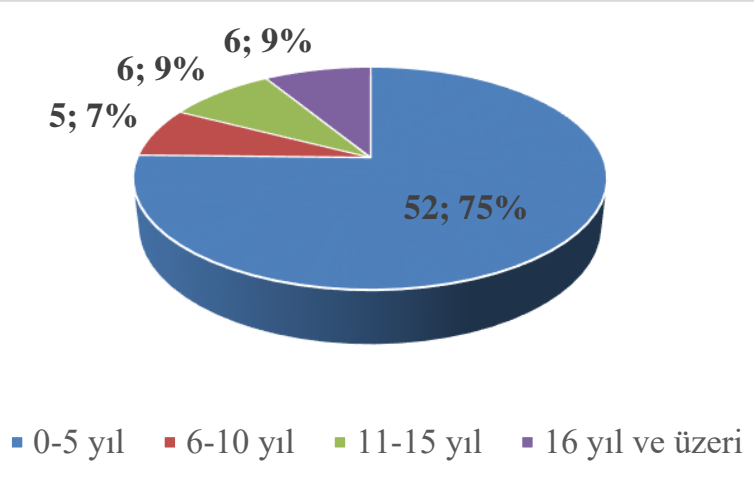

Şekil 3. İnşaat Mühendisi ve Mimar Gruplarından Elde Edilen RÖE Değerleri 
Literatürde RÖE $<0,6$ değeri önem derecesi düşük gösterge olarak, $0,6 \leq \mathrm{RÖE}<0,8$ ortalama gösterge olarak ve $0,8 \leq \mathrm{RÖE} \leq 1$ yüksek gösterge olarak tanımlanmaktadır (Artan İlter, 2017). Buna göre meslek grupları açısından önem arz eden göstergeler farklılık göstermektedir. İnşaat mühendisleri açısından en önemli göstergeler, sırasıyla; fenni mesul olarak mimar veya inşaat mühendislerinin $30.000 \mathrm{~m}^{2}$ den fazla inşaatın fenni mesuliyetini aynı anda üstlenmemesi (Soru 11, RÖE=0,79), gün 1şığı almayan bodrum kat dairelerinin yasaklanması (Soru 14, RÖE=0,78) ve TAKS'ın \%40'tan \%60'a çıkmasının yeşil alan sorunu oluşturacağı (Soru 3, $\mathrm{RÖE}=0,75$ ) olarak belirlenmiştir. Mimarlar açısından ise en önemli göstergeler, sırasıyla; gün ışığı almayan bodrum kat dairelerinin yasaklanması (Soru 14, RÖE=0,88), güneş kaynaklı yenilenebilir enerji sistemlerinde ruhsat şartı aranmaması (Soru 9, RÖE=0,80) ve inşaat ruhsatı beklenmeden mimari proje onayına müteakip kazı izni verilmesi imkânının getirilmesinin yatııımcıya zaman kazandıracak olması (Soru 16, RÖE $=0,78$ ) şeklinde belirlenmiştir.

İnşaat mühendisleri açısından önem derecesi en düşük göstergeler, sırasıyla; stüdyo dairelerin kaldırılması (Soru 12, RÖE=0,58), çarpık kentleşmenin ortadan kalkacağı inancı (Soru 1 ve 5 , RÖEort=0,57) ve BTK'nın uygun görüşü alınarak ruhsat alınmadan baz istasyonu kurulabilmesi (Soru 8, RÖE=0,54) olarak gösterilmektedir. Mimarlar açısından ise, sırasıyla; BTK'nın uygun görüşü alınarak ruhsat alınmadan baz istasyonu kurulabilmesi (Soru 8, RÖE=0,57), çarpık kentleşmenin ortadan kalkacağı inancı (Soru 1 ve 5 , RÖEort $=0,52$ ) ve yeni yönetmeliğin mimari estetiğe katkı sağlayacağı düşüncesi (Soru 6 , RÖE $=0,44$ ) olarak gösterilmektedir.

\section{Sonuç}

03/07/2017 tarihinde yayımlanarak yaklaşık üç ay gibi kısa süre sonra, 01/10/2017 tarihinde yürürlüğe giren yeni Planlı Alanlar İmar Yönetmeliği, eski Planlı Alanlar Tip İmar Yönetmeliği kapsamındaki mevcut prosedür ve ilkelere önemli değişiklikler getirmiş̧ir.

Yapılan en önemli değişikliklerden birisi en küçük daire büyüklüğünün $27,5 \mathrm{~m}^{2}$ 'den $28,5 \mathrm{~m}^{2}$ ye çıkarılmasıdır. Her ne kadar alan olarak bariz bir fark söz konusu olmasa da her daireye oturma odası ve yatak odası zorunluluğu getirilmesi, minimum 1+1 tasarımı zorunlu kılmaktadır. $\mathrm{Bu}$ da son yıllarda revaçta olan $1+0$ dairelerin artık tasarlanamayacağı anlamına gelmektedir. Bu hususta rölatif önem endeksi (RÖE) değerleri katılımcı inşaat mühendisleri $(\mathrm{RÖE}=0,58)$ ve mimarlar (RÖ̈E=0,59) tarafindan 'önem derecesi düşük' gösterge olarak görülmektedir.

Yine önemli bir değişiklik olarak görülen bodrum kat dairelere gün ışı̆̆ı alma koşulu getirilmesi hususunda (RÖE) değerleri, katılımcı inşaat mühendislerinin bu değişikliği 'ortalama gösterge' olarak ( $\mathrm{RÖE}=0,78)$ ve mimarların 'yüksek gösterge' olarak ( $\mathrm{RÖE}=0,88)$ gördüklerini ifade etmektedir. Her iki taraf açısından en önemli ilk üç göstergede ortak olan tek göstergenin bu olması dikkat çekmektedir. Özellikle 2012 yılında Samsun'da yaşanan sel felaketi sonrasında binaların bodrum katlarında yaşanan can kayıpları, yeni yönetmelikte bodrum kat dairelerin tasarlanmasını olanaksız hale getirmiştir. Bu hususta mimarlar, inşaat mühendislerine göre daha hassas bir tutum göstermektedirler.

Yeni yönetmelik kapsamında; çekme mesafeleri ve KAKS verilen ancak TAKS verilmeyen parsellerde TAKS'ın \%60'1 geçmemesi şartıyla çekme mesafelerine göre uygulama yapılabilmesi, bir başka ifadeyle TAKS'ın \%40'tan \%60'a çıkarılabilmesi, peyzaj alanlarının azaltılması açısından olumsuz bir durum olarak algılanmakla birlikte, yatay kentleşmeyi olumlu yönde etkileyecek bir girişimdir. Şöyle ki, yapının taban alanının artması, aynı inşaat alanının daha az katla tamamlanabilmesi anlamına gelmektedir. Bu değişikliği katılımcı inşaat mühendisleri $(\mathrm{RÖE}=0,64)$ ve mimarlar ( $\mathrm{RÖE}=0,61)$ benzer şekilde 'ortalama gösterge' olarak görmektedirler.

Kentlerdeki estetik şartının yerine getirilebilmesi amacıyla yapı ruhsatlarının onaylanmasında görev alacak 'Mimari Estetik Komisyonu' kurulması da yeni yönetmelikte yer bulan önemli bir düzenlemedir. Komisyonda yer alacak meslek grupları; mimar, peyzaj mimarı, mimarlık tarihçisi, sanat tarihçisi, inşaat mühendisi, çevre mühendisi, şehir plancısı ve harita mühendisi olarak tanımlanmıştır. Ancak katılımcı inşaat mühendisi $(\mathrm{RÖE}=0,59)$ ve mimarların ( $\mathrm{RÖE}=0,44)$ bu yeniliğe bakış açıları da 'önem derecesi düşük' göstergeyi aşamamaktadır. Burada dikkat çekici olan, inşaat mühendislerinin 'Mimari Estetik Komisyonu' kavramına mimarlara göre daha 1lımlı bakmalarıdır.

Bu çalışma, inşaat sektöründe önemli rolleri olan inşaat mühendisleri ve mimarların, 2017 yılında yürürlüğe giren Planlı Alanlar İmar Yönetmeliğine ve bu yeni yönetmelik kapsamında yapılan değişikliklere bakış açılarını belirlemek amacıyla gerçekleştirilmiştir. Çalışmanın, dikkate alınacak gösterge sayısı artırılarak ve/veya çeşitlendirilerek, bunun yanında örneklemi büyütülerek geliştirilmesi mümkündür.

\section{Kaynakça}

ALPAR, R. (2013), Uygulamalı Çok Değişkenli Istatistik Yöntemler, 4. Baskı, Detay Yayıncılık, Ankara.

ARTAN İLTER, D. (2017), Türk Yüklenici Firmaların Çevresel Performanslarının Analizi, IMO Teknik Dergi, yazı 474, 7795-7822.

BALCI, A. (2005), Sosyal Bilimlerde Araştırma, Pegem Yayıncıllk, Ankara.

BERNARDI, R.A. (1994), Validating Research Results When Cronbach's Alpha is Below .70: A Methodological Procedure, Educational and Psychological Measurement, 54(3), 766-775.

CHEN, T.L., and CHANG, H.S. (2018), The Effects of Zoning Regulations along Fault Zone Areas on Land Development and Property Values after the 921 Chi-Chi Earthquake in Taiwan, Sustainability, 10, 1175.

ÇAMBEL, E., ve ÖZGAN, E. (2018), Mimari Tasarım Sürecinde Mühendislik Sorunlarının Mimarlar Açısından İncelenmesi, İleri Teknoloji Bilimleri Dergisi, 7(2), 47-70.

ÇAY, T., ve ÖZEN, H. (1998), İmar Uygulamalarında Karşılaşılan Problemler ve Konya Örneği, TKMD Mülkiyet Dergisi, 28, 8-13. 
ÇEVRE VE ŞEHİRCILIKK BAKANLIĞI (2017), Planlı Alanlar İmar Yönetmeliği, $12.05 .2019 \quad$ tarihinde https://www.mevzuat.gov.tr/Metin.Aspx?MevzuatKod=7.5.23722\&MevzuatIliski=0\&sourceXmlSearch=planl\%C4\%B1\%20alanl ar adresinden alındı.

GÜNDÜZ, M., NIELSEN, Y., and ÖZDEMIR, M. (2013), Quantification of Delay Factors Using the Relative Importance Index Method for Construction Projects in Turkey, ASCE Journal of Management in Engineering, 29(2), 133-139.

İNAM, Ş., ÇAY, T., ve İŞCAN, F. (2015), Planlama ve İmar Kanunu Tasarısının Uygulanabilirliğinin Araştırılması, Selçuk-Teknik Dergisi, 14(1), 1-20.

MEMNUN, D.S., HART, L.C., and AKKAYA, R. (2012), A Research on the Mathematical Problem Solving Beliefs of Mathematics, Science and Elementary Pre-service Teachers in Turkey in Terms of Different Variables, International Journal of Humanities and Social Science, 2(24), 172-184.

ÖNGÖREN, G. (2017), "Yargı Kararları Işı̆̆ında" İmar Hukuku, Öngören Hukuk Yayınları, No 8, İstanbul.

ÖZKAYA, E. (2000), İmar Kanunu Şerhi ve Mevzuatı, 2. Baskı, Seçkin Yayıncılık, 1606 s, İstanbul.

SAĞLAM, İ. (2003), Belediyelerce Yapılan Uygulamalardan Hareketle İmar Planı Uygulama Sorunlarını Belirlenmesi, HKMO Bülteni, 13-18.

SONKAYA, İ. (2017), Imar Mevzuatının Mimari Tasarıma Getirdiği Sınırlamalar ve Uygulama Sorunlarının Konya Örneğinde İrdelenmesi, Yüksek Lisans Tezi, Selçuk Üniversitesi, Konya.

YILDIZ, D., ve UZUNSAKAL, E. (2018), Alan Araştırmalarında Güvenilirlik Testlerinin Karşılaştırılması ve Tarımsal Veriler Üzerine Bir Uygulama, Uygulamalı Sosyal Bilimler Dergisi, 2(1), 14-28.

YILDIZ, F. (1992), İmar Planı Uygulamaları ve Karş1laşılan Sorunlar, Harita Dergisi, Sayı:108, 21-29. 